\title{
Determinants of Stunting in the Eastern Indonesia Region Based on Indonesian Family Life Survey 5 Data
}

\author{
Iing Merillarosa Kharisma Wardani ${ }^{1}$ Siti Nurrochmah ${ }^{2 *}$, Dian Mawarni ${ }^{1}$ \\ ${ }^{1}$ Department of Public Health, Faculty of Sport Sciences, Universitas Negeri Malang, Malang, East Java, Indonesia \\ ${ }^{2}$ Department of Physical Education, Health, and Recreation, Faculty of Sport Sciences, Universitas Negeri Malang, \\ Malang, East Java, Indonesia \\ *Corresponding author. Email: siti.nurrochmah.fik@um.ac.id
}

\begin{abstract}
Stunting can lead to the decline in children's cognitive, motoric, and language functions, as well as various degenerative diseases during adulthood. The Eastern Indonesia (EI) region has the highest rate of stunting throughout the country. This study aims to identify and review the determinants of stunting in children aged 1-5 years old (12-60 months) in EI. This study employed an analytical cross-sectional design with secondary data sourced from the Indonesian Family Life Survey 5 (IFLS 5). The subjects were IFLS 5 child respondents aged 1-5 years old (12-60 months) living in EI. The dependent variable in this study was stunting incidence. The independent variables include consumption of animal source foods, history of diarrhea in children, and visits to Posyandu. The data were analyzed in univariate and bivariate manners with a chi-square test, and multivariately with a logistic regression test. The bivariate analysis shows that there was no relationship between consumption of animal source foods $(\mathrm{p}=0.173)$, history of diarrhea $(\mathrm{p}=0.801)$, and visits to Posyandu $(\mathrm{p}=0.061)$ and the stunting incidence. The univariate analysis shows that there was no relationship between consumption of animal source foods $(\mathrm{p}=0.182 ; \mathrm{OR}=1.298 ; 95 \% \mathrm{CI}=0.884-1.906)$, history of diarrhea $(\mathrm{p}=0.955 ; \mathrm{OR}=1.011 ; 95 \% \mathrm{CI}=0.691-1.479)$, and visits to Posyandu ( $\mathrm{p}=0.079 ; \mathrm{OR}=0.079 ; 95 \%$ $\mathrm{CI}=0.584-1.030$ ) and the stunting incidence in children aged 1-5 years old in EI. Consumption of animal source foods, history of diarrhea, and visits to Posyandu are not the determinants of stunting in Eastern Indonesia.
\end{abstract}

Keywords: determinant, Eastern Indonesia, stunting

\section{INTRODUCTION}

Healthy and optimal child growth is every parent's hope. However, the majority of children in the country are malnourished, indicated by, among others, stunting. Stunting is defined as a condition where a child's height-for-age is -2 standard deviations below the WHO child growth standards median. It causes children to have shorter heights compared to the height of children their age [1]. Around 149 million children in the world $(21.9 \%)$ in 2018 were affected by stunting [2]. Meanwhile, in 2019, the stunting rate in Indonesia reached $27.7 \%$, exceeding the threshold of the prevalence of stunting according to WHO of less than $20 \%$ [3].

Stunting paves the way for other more serious problems later in life. The common short-term impact is low cognitive function in children [4]. The long-term impact is related to metabolic disorders as children grow up. These metabolic disorders make a person susceptible to obesity, diabetes mellitus and other degenerative diseases [5]. It may affect the quality of future human resources in Indonesia, preventing them to compete with other nations and leading to the country's economic burden due to high morbidity [6].

Consuming a varied diet including animal source foods especially for children under five years old (toddler) is vital in supporting children growth process. Diet variety and specific consumption of animal protein are also mentioned in the determinants of stunting according to WHO [7]. The types of amino acids in animal source foods are more complete when compared to protein sources from plant foods. Animal foods also possess better protein, vitamin, and mineral contents [8]. A study shows that toddlers affected by stunting tend to consume less animal foods compared to toddlers with normal nutritional status [9].

Diarrhea is also one of the risk factors of malnutrition disorders in children such as stunting or wasting because the body is unable to properly absorb essential nutrition needed for optimal growth and 
development [10]. Meanwhile, several previous studies on the relationship between diarrhea history and stunting incidence obtained significant results. A study by Hairuddin (2018) shows increased risk of stunting by 2.61 times in children with a history of diarrhea [11]. Another study in Aceh Province shows increased risk of stunting by 5.04 times in children with a history of diarrhea [12].

Visits to Posyandu also has an effect on stunting. Posyandu is poised to be a facility affordable and reachable by the community to access information on the health of children under five. Furthermore, Posyandu can also closely monitor children's nutritional status. Previous studies show increased risk of stunting by 4 times in children who do not actively visit the Posyandu [13]. In a study by Tsaralatifah (2020), the frequency of Posyandu visits is significantly associated with stunting [14].

The region of Eastern Indonesia (EI) is any island apart from the islands of Java, Sumatra and Bali. Four out of five provinces with the highest rate of stunting in Eastern Indonesia are East Nusa Tenggara Province (42.6\%), West Sulawesi (41.6\%), South Sulawesi (35.7\%), and Central Kalimantan (34\%) [3]. Many studies have investigated the determinants of stunting; however, few have touched the topic in EI. A study of the determinants of stunting can be carried out by utilizing secondary data sources such as Indonesia Family Life Survey (IFLS).

IFLS is a longitudinal survey carried out by Research and Development Corporation (RAND) since 1993. To date, the survey has been held five times, with IFLS 5 conducted in 2014 to early 2015 being the most recent. There are 13 provinces in Indonesia included in IFLS as subjects, with three of those located in the eastern part of Indonesia, namely the provinces of West Nusa Tenggara, South Sulawesi, and South Kalimantan.

This study aims to identify and review the determinants of stunting in children aged 1-5 years old (12-60 months) in EI by investigating the risk factors for stunting, namely consumption of animal source foods, history of diarrhea and history of Posyandu visits.

\section{MATERIAL AND METHOD}

This study used an analytical survey design with a quantitative approach. The design of the study was analytical cross-sectional utilizing secondary data sourced from Indonesian Family Life Survey 5 (IFLS 5) in 2014-2015. The research location was Eastern Indonesia (EI) which was the subject of IFLS 5. There were three targets EI provinces in the IFLS, namely the provinces of West Nusa Tenggara, South Sulawesi, and South Kalimantan. However, since IFLS is a longitudinal survey, the number of provinces that were included might increase if there were respondents from the previous surveys who migrated to other provinces, thus, they are still listed as IFLS respondents.
The dependent variable used was stunting incidence in children aged 1-5 years old (12-60 year) in EI. The independent variables included consumption of animal source foods, history of diarrhea and visits to Posyandu.

The study used the total sampling method with the subjects of all children aged 1-5 years (12-60 months) who were registered as IFLS 5 respondents and resided in EI. Respondents with incomplete questionnaire result data and a z-score for body height/length-for-age outside the range of -6 to +6 standard deviation (WHO limit range) were excluded from the study. The initial subjects were 823 respondents and after the exclusion process, 805 respondents were obtained for analysis (Figure 1)

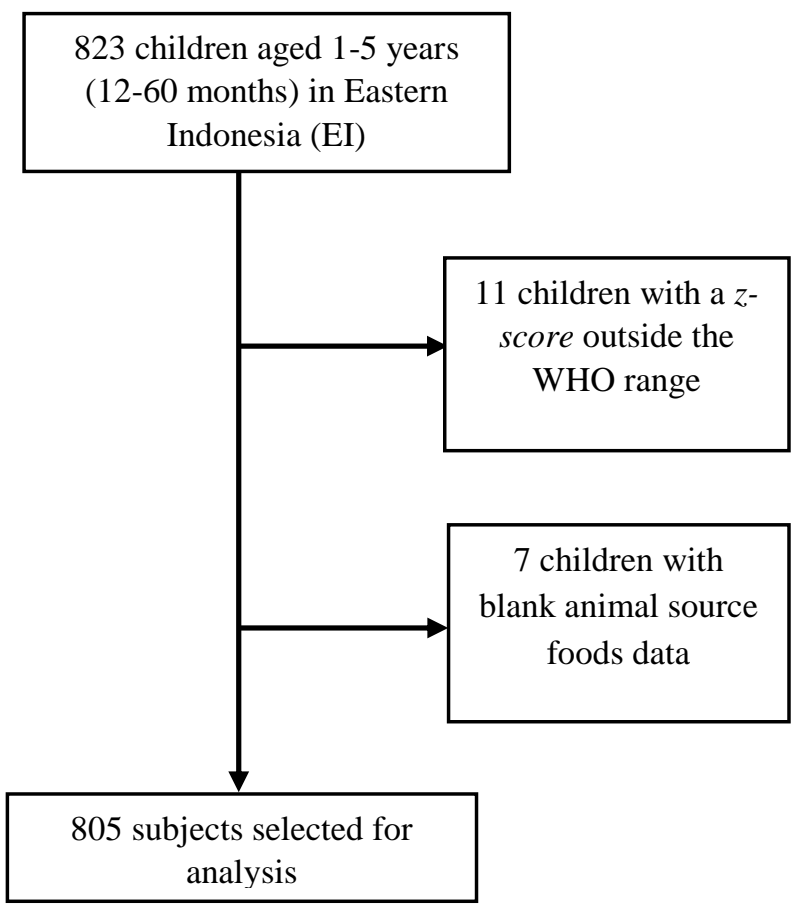

Figure 1 Sampling process of research analysis subjects

The instrument in this study WAS a non-test technique in the form of a document recording the results of IFLS 5 which WAS derived from the results of household questionnaires in Book 4, Book 5, and Book US. The initial stage of the study was to collect data in the form of records of toddler's height/length, toddler's age, consumption of animal source foods, history of diarrhea, and Posyandu visits which are available open access on the RAND Labor and Population website. Furthermore, the data were processed and categorized into a nominal scale for analysis. Stunting incidence data processing was carried out using the STATA 12.1 computer program with the command "zscore 06 " to obtain z-scores of the children's height/length-for-age. The command "zscore06" is a STATA syntax created by Jef L Leroy (2011) from the International Food Policy Research Institute to calculate the z-score based on WHO child growth standards [15]. 
The data in this study were processed bivariately using chi-square test and multivariately with logistic regression with the help of the STATA 12.1. computer program. The purpose of the bivariate analysis was to identify the relationship between the independent variables and the dependent variable with the results considered related if p-value $<0.05$ (CI 95\%). The purpose of the multivariate analysis was to identify the effect of the independent variables along with the dependent variable.

\section{RESULT}

\subsection{Overview of respondent's stunting incident, consumption of animal foods, history of diarrhea and visits to Posyandu}

Table 1. Overview of respondent's stunting incident, consumption of animal foods, history of diarrhea and visits to Posyandu

\begin{tabular}{|l|c|c|}
\hline Respondent Characteristics & n (person) & \% \\
\hline Stunting & 351 & 43.60 \\
Yes & 454 & 56.40 \\
No & 680 & \\
\hline Animal foods consumption & 84.47 \\
Adequate & 125 & 15.53 \\
Inadequate & 675 & \\
\hline History of diarrhea & 130 & 16.85 \\
No & & \\
Yes & 344 & 42.73 \\
\hline Visits to Posyandu & 461 & 57.27 \\
Yes & \\
No &
\end{tabular}

Table 1 shows that the proportion of stunting in children aged 1-5 years in Eastern Indonesia was $43.60 \%$. Most respondents $(84.47 \%)$ consumed at least one type of animal foods every day, be it eggs, fish, meat, or milk and their products. The majority of respondents $(83.85 \%)$ had no history of diarrhea in the last four weeks. The majority of respondents $(57.27 \%)$ did not visit the Posyandu in the last four weeks.

\subsection{Analysis of the relationship between animal source foods, history diarrhea and Posyandu visits and stunting in Eastern Indonesia}

Table 2 of the results of the chi square test shows that there is no relationship between animal foods consumption and stunting incidence in children in Eastern Indonesia with $p=0.141$ ( $p>0.05)$. There is no relationship between history of diarrhea and stunting incidence in children with $\mathrm{p}=0.799$ ( $\mathrm{p}>0.05)$. Meanwhile, the results of the chi square test analysis on the Posyandu visit variable show a value of $\mathrm{p}=0.062$ $(\mathrm{p}>0.05)$, which means that there is no relationship between Posyandu visits and stunting in Eastern Indonesia.
Table 2. Bivariate analysis of the relationship between animal source foods, history of diarrhea and visits to Posyand $u$ and stunting in Eastern Indonesia

\begin{tabular}{|c|c|c|c|c|c|}
\hline \multirow[t]{3}{*}{ Variables } & \multicolumn{4}{|c|}{ Stunting } & \multirow[t]{3}{*}{ p-value } \\
\hline & \multicolumn{2}{|c|}{ Yes } & \multicolumn{2}{|c|}{ No } & \\
\hline & $\mathrm{n}$ & $\%$ & $\mathrm{n}$ & $\%$ & \\
\hline $\begin{array}{l}\text { Animal } \\
\text { foods } \\
\text { consumption }\end{array}$ & & & & & 0.141 \\
\hline Adequate & 62 & 7.70 & 63 & 7.83 & \\
\hline Inadequate & 289 & 35.90 & 391 & 48.57 & \\
\hline $\begin{array}{l}\text { History of } \\
\text { diarrhea }\end{array}$ & & & & & 0.799 \\
\hline Yes & 58 & 7.20 & 72 & 8.94 & \\
\hline No & 293 & 36.40 & 382 & 47.45 & \\
\hline Visit & & & & & \\
\hline Posyandu & & & & & 0.062 \\
\hline No & 188 & 23.35 & 273 & 33.91 & \\
\hline Yes & 163 & 20.25 & 181 & 22.48 & \\
\hline
\end{tabular}

\subsection{Determinants of stunting in Eastern Indonesia}

Table 3. Multivariate analysis of the determinants of stunting in Eastern Indonesia

\begin{tabular}{|l|c|c|}
\hline \multicolumn{1}{|c|}{ Variable } & p-value & OR $(\mathbf{9 5 \%}$ CI) \\
\hline $\begin{array}{l}\text { Animal foods } \\
\text { consumption }\end{array}$ & 0.182 & $1.298(0.884-1.906)$ \\
\hline $\begin{array}{l}\text { History of } \\
\text { diarrhea }\end{array}$ & 0.955 & $1.011(0.691-1.479)$ \\
\hline Visit Posyandu & 0.079 & $0.775(0.584-1.030)$ \\
\hline
\end{tabular}

Table 3 which contains the results of the multivariate analysis using logistic regression shows that there is no effect of animal foods consumption ( $\mathrm{p}=0.182$; $\mathrm{OR}=$ $1.298 ; 95 \% \mathrm{CI}=0.884-1.906)$, history of diarrhea $(\mathrm{p}=$ $0.955 ;$ OR $=1.011 ; 95 \% \mathrm{CI}=0.691=1.479)$, and Posyand $u$ visits $(\mathrm{p}=0.079 ; \mathrm{OR}=0.079 ; 95 \% \mathrm{CI}=$ 0.584-1.030) on stunting incidence in Eastern Indonesia.

\section{DISCUSSION}

\subsection{Relationship Between Animal Foods Consumption and Stunting Incidence}

The results of the analysis on the animal foods consumption variable with stunting incidence show that most respondents $(84.47 \%)$ consumed animal source foods every day for one week. In the results of the bivariate analysis, a $\mathrm{p}$ value $=0.141(\mathrm{p}>0.05)$ was obtained which means that there is no significant relationship between animal food consumption and stunting incidence. Meanwhile, the results of the multivariate analysis show that there is no relationship between animal food consumption and stunting incidence with $\mathrm{p}=0.182(\mathrm{p}>0.05)$. The study found that 
the majority of respondents who consumed animal food sources every day did not experience stunting (48.57\%).

The amino acid content in animal foods is more complete and more easily absorbed by the body when compared to plant foods. Although protein sources can be obtained from plant foods such as nuts, the nutrients found in animal source foods are irreplaceable [8].

In this study, no meaningful relationship was found between consumption of animal foods and stunting incidence which may be attributable to other factors affecting stunting incidence in the population. In addition, this study did not distinguish between variations in types of animal source foods consumed by the respondents. Animal source foods include eggs, fish, meat, milk and their products. Each animal food has distinct nutritional content and benefits for the body. The results of this study are in line with a study conducted in Bandung on children aged 1-5 years old demonstrating no significant relationship between animal source foods and stunting [16]. However, despite no significant relationship was found, consumption of animal foods is significantly correlated with adequate intake of protein and micronutrients, especially Vitamins $\mathrm{A}, \mathrm{Ca}$, and $\mathrm{Zn}$. It shows that consumption of animal foods provides considerable benefits for child growth [16].

A study involving children aged 6-23 months old across 21 developing countries shows different results where increased risk of stunting by 1.436 times was observed in children that did not consume three types of animal foods (eggs, meat, milk and its products) [17]. Animal foods are an important source of high-quality nutrition. Dietary diversity is part of WHO strategic measures to reduce stunting rate in children aged below 5 years old by $40 \%$ by 2025 [18].

Egg consumption can significantly increase the $\mathrm{Z}$ score $\mathrm{PB} / \mathrm{U}$ by 0.63 times compared to children who do not consume eggs [19]. Eggs possess great benefits for improving maternal and child nutrition, especially in developing countries. Eggs are rich in essential fatty acid, choline, vitamin A, vitamin B12, iron, zinc, and iodine for child growth. People with low economic levels are at high risk of suffering from these nutritional deficiencies, thus eggs can be a good and affordable choice of food sources [20].

Fish has been shown to make an important contribution to improving the nutritional status of children aged 6-59 months in the poor in Zambia. Children aged 24-59 months that do not consume fish have a 1.038 times higher risk of suffering from stunting than those who do [21]. Fish is known as a source of essential nutrition such as amino acid, DHA, vitamin, and minerals needed for brain growth and development. High rates of stunting in African countries such as Burundi (55\%), Kenya (38\%), Tanzania (34\%), and Uganda (28\%) are in line with the low fish consumption/capita (2205 ccal/capita/day) compared to the global average (2900/ccal/capita/day) [22].
A study in Ethiopia involving children 6-59 months shows that children who do not consume meat have a 2.4 times higher risk of stunting compared to those who do every day [23]. Consuming milk and other animal source foods can improve the anthropometry index in malnourished children. Furthermore, it can prevent deficiencies or malnutrition, improve cognitive function, reduce morbidity and prevent death in children [24].

\subsection{Relationship Between History of Diarrhea and Stunting Incidence}

The analysis results of history of diarrhea with stunting incidence showed that the majority of respondents did not have a history of diarrhea in the last 4 weeks. After the chi square test, a $p$ value $=0.799(p>$ $0.05)$ was obtained which means that there is no significant relationship between history of diarrhea and stunting incidence, thus $\mathrm{H}_{0}$ is accepted. The results of the multivariate analysis show that there was no effect between history of diarrhea and stunting incidence with $p=0.955(p>0.05)$. The results show that the majority of the respondents who did not have a history of diarrhea during the last 4 weeks did not experience stunting $(47.45 \%)$. Diarrhea causes the body to expend fluid and nutrients and if these are not replenished as soon as possible, dehydration, malnutrition, growth impairment such as stunting, and even death may occur [25].

In this study, no meaningful relationship was found between history of diarrhea and the stunting incidence which may be attributable to other factors affecting stunting incidence in the population. In addition, this study could only identify history of diarrhea for the last 4 weeks. The results of this study are in line with a study in Surabaya in children aged 13-48 months showing there is no significant relationship between a history of diarrhea and stunting [26].

A study in East Nusa Tenggara shows a contrasting result where a history of two diarrheas children under two years of age can increase the risk of stunting by 2.55 times. The observation was conducted for cases in the last 6 months [27]. A study with children aged 6-59 months in Nepal also shows significant results. A history of diarrhea in the last two months translates into increased risk of stunting by 7.46 times [28]. A study in Malawi on children aged 6-18 months reveals that the longer a diarrhea persists in a child, the lower the $\mathrm{z}$ score $\mathrm{PB} / \mathrm{U}$ would be, meaning that the resulting stunting would be more severe. It could be because the digestive tract cannot absorb the nutritional content of food optimally, so that it affects the growth and development of the child [29]. Previous studies showing significant results on average use history of diarrhea data at least in the last two months. 


\subsection{Relationship Between Visit Posyandu with Stunting Incidence}

The analysis of the relationship between the Posyandu visits variable and the stunting incidence show that the majority of the respondents did not visit the Posyandu in the last 4 weeks. After the bivariate analysis, a $\mathrm{p}=0.062(\mathrm{p}>0.05)$ was obtained meaning that there is no significant relationship between visits to Posyandu and the stunting incidence, thus, $\mathrm{H}_{0}$ is accepted. The results of the multivariate analysis show that there is no relationship between visits to Posyandu and the stunting incidence with $\mathrm{p}=0.079$ ( $\mathrm{p}>0.05)$. According to this study, the majority of the respondents who did not visit the Posyandu in the last 4 weeks did not suffer from stunting $(33.91 \%)$.

Through the Posyandu initiative, the community has easier access to basic health services for mothers and children such as weighing toddlers to monitor nutritional status, health consultations, and other health checks. Posyandu is a facility to access various health information including that regarding child growth and development [30]. In Posyandu, children's monthly nutritional status can be monitored. Without regular visits, children's nutritional status cannot be monitored properly and any decline in nutritional status cannot be immediately detected. Furthermore, children's mothers who regularly visit the Posyandu are exposed to the latest information regarding child growth and development [14].

A study in Belu District, East Nusa Tenggara also obtains an insignificant relationship between visits to Posyandu and stunting [31]. However, a study on children in Palembang manages to record increased risk of stunting by 3.5 times in children without regular visits to the Posyandu and by 5.2 times in children who never visited the Posyandu [32].

In this study, no meaningful relationship was found between visits to Posyandu and the stunting incidence which may be attributable to other factors affecting stunting incidence in the population. In addition, limitations in this study did not allow us to measure the frequency of Posyandu visits for the last one year, only for the last 4 weeks.

This study only reviews the determinants of stunting in Eastern Indonesia (EI) in 2014-2015 due to the limited nature of our secondary data source, IFLS 5 conducted in 2014-2015.

\section{CONCLUSION}

Based on the results of the study, we can conclude that consumption of animal foods, history of diarrhea, and Posyandu visits are not significantly related to the incidence of stunting in children aged 1-5 years in Eastern Indonesia. Overall, there is no relationship between animal foods consumption, history of diarrhea, and Posyandu visits to the incidence of stunting in children aged 1-5 years in Eastern Indonesia.

\section{AUTHORS' CONTRIBUTIONS}

IMK wrote the the manuscript with support from SN dan DM All authors discussed the results and contributed to the final manuscript.

\section{ACKNOWLEDGMENTS}

The authors thank to RAND that provided the open source for accessing the IFLS wave 5 data. Gratitude also expressed to Faculty of Sport Sciences, Universitas Negeri Malang that support this study.

\section{REFERENCES}

[1] Kementerian Kesehatan RI, "Buletin Stunting," 2018.

[2] Unicef/ World Health Organization/The World Bank, "Levels and Trends in Child malnutrition Unicef WHO The World Bank Joint Child Malnutrition Estimates, key findings pf the 2019 edition," Unicef, hal. 1-16, 2019.

[3] Kementerian Kesehatan RI, "Laporan Nasional Riset Kesehatan Dasar 2018,” hal. 1-582, 2018.

[4] T. Woldehanna, J. R. Behrman, dan M. W. Araya, "The effect of early childhood stunting on children's cognitive achievements: Evidence from young lives Ethiopia," Ethiop. J. Heal. Dev., vol. 31, no. 2, hal. 75-84, 2017.

[5] E. D. L. Rolfe et al., "Associations of stunting in early childhood with cardiometabolic risk factors in adulthood," PLoS One, vol. 13, no. 4, hal. 113, 2018.

[6] Kemendesa, "Buku saku desa dalam penanganan stunting," Buku Saku Desa Dalam Penanganan Stunting, hal. 42, 2017.

[7] WHO, "Childhood Stunting: Context, Causes and Consequences WHO Conceptual Framework," Who, vol. 9, no. 2, hal. 27-45, 2013.

[8] Kementerian Kesehatan RI, "Peraturan Menteri Kesehatan Republik Indonesi Nomor 41 Tahun 2014 tentang Pedoman Gizi Seimbang.” 2014.

[9] F. Ernawati, M. Prihatini, dan A. Yuriestia, "Gambaran Konsumsi Protein Nabati dan Hewani Pada Anak Balita Stunting dan Kurang Gizi di Indonesia," Penelit. Gizi dan Makanan, vol. 39, no. 2, hal. 95-102, 2016.

[10] R. Susilaningrum, Nursalam, dan S. Utami, Asuhan Keperawatan Bayi dan Anak: untuk Perawat dan Bidan Edisi 2. Jakarta: Salemba Medika, 2013.

[11] A. Hairuddin, "Penyakit Infeksi Dan Praktek 
Pemberian Mp-Asi Terhadap Kejadian," J. Dunia Gizi, vol. 1, no. 1, hal. 52-58, 2018.

[12] W. Lestari, A. Margawati, dan Z. Rahfiludin, "Faktor risiko stunting pada anak umur 6-24 bulan di kecamatan Penanggalan kota Subulussalam provinsi Aceh," J. Gizi Indones. (The Indones. J. Nutr., vol. 3, no. 1, hal. 37-45, 2014.

[13] Dahliansyah, M. Ginting, dan Desi, "Riwayat Posyandu Dan Asi Eksklusif Dengan Kejadian Stunting Anak Usia 6-59 Bulan Di Wilayah Kelurahan Siantan Hulu Kota Pontianak," Darussalam Nutr. J., vol. 4, no. 2, hal. 128-134, 2020.

[14] R. Tsaralatifah, "Faktor yang Berhubungan dengan Kejadian Stunting pada Baduta di Kelurahan Ampel Kota Surabaya," Amerta Nutr., vol. 4, no. 2, hal. 171-177, 2020.

[15] J. L. Leroy, zscore06: Stata Command for The Calculation of Anthropometric z-scores using The 2006 WHO Child Growth Standards. Washington DC: International Food Policy Research Institute, 2011.

[16] S. Muslimatun dan L. A. Ari Wiradnyani, "Dietary diversity, animal source food consumption and linear growth among children aged 1-5 years in Bandung, Indonesia: A longitudinal observational study," Br. J. Nutr., vol. 116, no. S1, hal. S27-S35, 2016.

[17] J. Krasevec, X. An, R. Kumapley, F. Bégin, dan E. A. Frongillo, "Diet quality and risk of stunting among infants and young children in low- and middle-income countries," Matern. Child Nutr., vol. 13, no. S2, hal. 1-11, 2017.

[18] WHO, "World health assembly global nutrition targets 2025: stunting policy brief," 2014.

[19] L. L. Iannotti et al., "Eggs in early complementary feeding and child growth: A randomized controlled trial," Pediatrics, vol. 140, no. 1, hal. 1-9, 2017.

[20] L. L. Iannotti, C. K. Lutter, D. A. Bunn, dan C. P. Stewart, "Eggs: The uncracked potential for improving maternal and young child nutrition among the world's poor," Nutr. Rev., vol. 72, no. 6, hal. 355-368, 2014.

[21] P. A. Marinda, S. Genschick, C. KhayekaWandabwa, R. Kiwanuka-Lubinda, dan S. H. Thilsted, "Dietary diversity determinants and contribution of fish to maternal and underfive nutritional status in Zambia," PLoS One, vol. 13, no. 9, hal. 1-18, 2018.

[22] K. Obiero et al., "The contribution of fish to food and nutrition security in Eastern Africa: Emerging trends and future outlooks," Sustain., vol. 11, no. 6, hal. 1-15, 2019.

[23] S. Eshete Tadesse, T. Chane Mekonnen, dan M. Adane, "Priorities for intervention of childhood stunting in northeastern Ethiopia: A matched case-control study," PLoS One, vol. 15, no. 9, hal. 1-13, 2020.

[24] D. K. Dror dan L. H. Allen, "The importance of milk and other animal-source foods for children in low-income countries," Food Nutr. Bull., vol. 32, no. 3, hal. 227-243, 2011.

[25] K. G. Dewey dan D. R. Mayers, "Early child growth: How do nutrition and infection interact?," Matern. Child Nutr., vol. 7, no. SUPPL. 3, hal. 129-142, 2011.

[26] C. A. Safitri dan T. S. Nindya, "Hubungan Ketahanan Pangan dan Penyakit Diare dengan Stunting pada Balita 13-48 Bulan di Kelurahan Manyar Sabrangan, Surabaya," Amerta Nutr., vol. 1, no. 2, hal. 52-61, 2017.

[27] N. N. Ilma, H. Salimo, dan E. P. Pamungkasari, "Prevalence and Path Analysis on the Effects of Diarrhea and Life Course Determinants on Stunting in Children Under Two Years of Age in Kupang, East Nusa Tenggara," J. Matern. Child Heal., vol. 4, no. 4, hal. 230-241, 2019.

[28] R. Paudel, B. Pradhan, R. R. Wagle, D. P. Pahari, dan S. R. Onta, "Risk factors for stunting among children: A community based case control study in Nepal," Kathmandu Univ. Med. J., vol. 10, no. 39, hal. 18-24, 2012.

[29] A. Weisz, G. Meuli, C. Thakwalakwa, I. Trehan, K. Maleta, dan M. Manary, "The duration of diarrhea and fever is associated with growth faltering in rural Malawian children aged 6-18 months," Nutr. J., vol. 10, no. 1, hal. 2-5, 2011.

[30] E. Saepuddin, E. Rizal, dan A. Rusmana, "Posyandu Roles as Mothers and Child Health Information Center," Rec. Libr. J., vol. 3, no. 2, hal. 201-208, 2017.

[31] S. S. Tatu, D. T. Mau, dan Y. M. Rua, "FaktorFaktor Resiko Yang Berhubungan Dengan Kejadian Stunting Pada Balita Di Desa Kabuna Kecamatan Kakuluk Mesak Kabupaten Belu," J. Sahabat Keperawatan, vol. 3, no. 01, hal. 1-17, 2021.

[32] N. F. Rahmawati, N. A. Fajar, dan H. Idris, "Faktor sosial, ekonomi, dan pemanfaatan posyandu dengan kejadian stunting balita keluarga miskin penerima PKH di Palembang," $J$. Gizi Klin. Indones., vol. 17, no. 1, hal. 23-33, 2020. 